Abstracta Iranica

Revue bibliographique pour le domaine irano-aryen

Volume 40-41 | 2019

Comptes rendus des publications de 2017-2018

\title{
Gian Pietro Basello. "Of Gods and Men in the Persepolis Bronze Plaque"
}

\section{Salman Aliyari Babolghani}

\section{(2) OpenEdition \\ 1 Journals}

\section{Electronic version}

URL: http://journals.openedition.org/abstractairanica/50096

DOI: 10.4000/abstractairanica.50096

ISBN: 1961-960X

ISSN: 1961-960X

Publisher:

CNRS (UMR 7528 Mondes iraniens et indiens), Éditions de l'IFRI

Electronic reference

Salman Aliyari Babolghani, "Gian Pietro Basello. "Of Gods and Men in the Persepolis Bronze Plaque"", Abstracta Iranica [Online], Volume 40-41 | 2019, document 90, Online since 30 December 2019, connection on 22 April 2021. URL: http://journals.openedition.org/abstractairanica/50096 ; DOI: https://doi.org/10.4000/abstractairanica.50096

This text was automatically generated on 22 April 2021.

Tous droits réservés 
Gian Pietro Basello. "Of Gods and Men in the Persepolis Bronze Plaque"

Salman Aliyari Babolghani 


\section{REFERENCES}

Gian Pietro Basello. "Of Gods and Men in the Persepolis Bronze Plaque" in W.F.M. Henkelma, C. Redard (eds.). Persian Religion in the Achaemenid Period. (Classica et Orientalia 16), 2017, Wiesbaden, p. 347-383

1 The object studied in this article is a bronze plaque (ca. $21.0 \times 32.5 \times 0.5 \mathrm{~cm}$ ) found at Persepolis (abbreviated as PBP) and inscribed in Elamite on the two faces. G.P. Basello here argues both the function of the object and the concept of its difficult text.

Despite mentioning some similarities between PBP and Persepolis Fortification tablets (e.g. the proper name u-ru-ru, the role of ${ }^{A N}{ }^{N} \breve{a}$-tin 'cult officiant', the toponym ké-sa-at, the cultic activity called ${ }^{A N} \check{S} u$-ip, female workers called ${ }^{M U N U S} a m-m a-l u-i p-p \grave{e}$, etc.), the author asserts that the lexicon, textual formulas, palaeography and mentioned gods show that PBP stems from the pre-Achamenid cultural context and dates the text in the late Neo-Elamite period.

3 He believes that some items like $M U S{ }^{2} N^{M E S ̌} . . . T I^{M E S ̌} . . . d u-i \check{s}-n i$ 'bird... arrow... may he receive' in PBP remind the Susa Acropole tablets where GIšBANMEš 'bows' and related items are received by a god [as offerings]. So, he recognizes PBP as an official and prescriptive document in the frame of which single offerings had to be performed. Furthermore, comparing PBP with a Hittite metal tablet from Hattuša (Bo 86/299 = CTH 106.A.1) which represents a close formal parallel, he suggests that it may be related to a commitment or obligation taken by a high-rank entity towards another one in front of a third party of witnesses and it had to be hung in some related institution like a temple, a royal palace, etc.

\section{AUTHORS}

\section{SALMAN ALIYARI BABOLGHANI}

Iran 